MARIOLA PAWEtKO ${ }^{1}$

\title{
SÁPMI. ZIEMIA SAMÓW A FORMOWANIE GRANIC KRAJÓW PÓŁNOCNEJ EUROPY
}

Słowa kluczowe: Samowie, Szwecja, Norwegia, Finlandia, Półwysep Kolski

\section{WPROWADZENIE}

Samowie tworzą rdzenną społeczność od wieków zamieszkującą północne obszary Europy. Współcześnie są to rubieże Norwegii, Szwecji, Finlandii oraz Półwyspu Kolskiego w Rosji, nazywane Półwyspem Fennoskandzkim². Na tak rozległym obszarze leży Sápmi - Ziemia Samów - kulturowo żywa przestrzeń, ściśle związana z samską tożsamością. W zależności od dialektu ${ }^{3}$ słowo przyjęte na określenie samskiej ziemi nieco się różni ${ }^{4}$, jednak znaczenie pozostaje takie samo.

W przeszłości Samowie zamieszkiwali obszary Fennoskandii, jednak wraz z przybyciem osadników z południa ziemia została podzielona

${ }^{1}$ Mgr; Uniwersytet Jagielloński w Krakowie; ORCID: 0000-0001-5896-0184; e-mail: mariola.pawelko@gmail.com.

2 Por. J. Donner, The Fennoscandian Shield Within Fennoscandia, „Bulletin of the Geological Society of Finland" 1996, nr 68 (1), s. 99-103; T. Kuuluvainen, T. Aakala, Natural Forest Dynamics in Boreal Fennoscandia: A Review and Classification, "Silva Fennica" 2011, nr 45 (5), s. 823-841.

${ }^{3}$ Obecnie wyróżnia się następujące dialekty: północnosamski, południowosamski, ume, pite, lule, inari, skolt, akkala/babino, kildin, ter. Więcej na ten temat w następujących, bardzo szczegółowych opracowaniach: H. Rydving, Words and Varieties. Lexical Variation in Saami, Helsinki 2013; P. Sammallahti, Saamic, [w:] The Uralic Languages, red. D. Abondolo, London - New York 1998, s. 43-95; Saami Linguistics, red. D.C. Nelson, I. Toivonen, Amsterdam - Philadelphia 2007.

${ }^{4}$ Wśród najczęściej spotykanych określeń - oprócz Sápmi - znajdują się Sábme, Sábmie, Saepmie lub Sámieanan. 
granicami, natomiast autochtonów zepchnięto ku północy, w miejsca leżące blisko Morza Norweskiego i Morza Barentsa. Cykliczne wędrówki Samów, polowania i połowy ryb, którymi się trudnili, stały się w efekcie transgraniczne. Tradycyjne granice wytyczone przez samskich przodków zostały zignorowane przez "nową” skandynawską, ale też pozaskandynawską kulturę.

Problem podjęty $w$ artykule został przedstawiony w następujący sposób: w pierwszej części omawiam aspekty historyczne i religijne dotyczące formowania się wspólnoty Samów, by dalej przejść ku zjawiskom należącym do sfery społeczno-politycznej. Jest to o tyle istotne, że na przełomie XVII i XVIII wieku doszło do swoistej modernizacji samskiej kultury, która tym samym nabrała dynamizmu w stosunku do tego, co było przedtem; drugą część artykułu poświęcam Samom z Półwyspu Kolskiego w Rosji. Koncentruję się na skutkach działań politycznych zwłaszcza z przełomu XIX i XX wieku, podejmowanych zarówno przez Samów, jak i przez władze państwowe.

Prześledzenie wydarzeń z historii, religii, polityki oraz generalnie relacji mniejszość - większość pomoże zrozumieć, dlaczego w kulturze Samów wyolbrzymiony wstyd stał się narzędziem zarządzania tą grupą. Koncentrując się na tym a nie innym temacie, staram się ukazać specyfikę działań państwa wobec Samów, podlegających w istocie kolonizacji ${ }^{5}$.

\section{KONIEC CZASU BĘBNA}

Pierwsze bezpośrednie udokumentowane kontakty ludności samskiej z przedstawicielami społeczności z południa miały miejsce we wczesnym

\footnotetext{
${ }^{5}$ Problemem kolonizacji w kontekście globalnym zajmują się przede wszystkim badacze z ośrodków naukowych w USA, Wielkiej Brytanii i Francji oraz naukowcy pochodzący z rejonów byłych kolonii. Wśród głównych teoretyków należy wymienić takie znakomitości, jak Leela Ghandi, Dipesh Chakrabarty, Ania Loomba, Gayatri Chakravorty Spivak, Robert J.C. Young oraz Edward Said. W kontekście nordyckim koniecznie należy przywołać takich badaczy, jak Gunlög Fur, Kristin Loftsdóttir, Jonas M. Nordin oraz Fredrik Ekengren. Na polu polskiej nauki można dostrzec trzy tendencje: (1) zorientowanie na Bliski i Daleki Wschód, Amerykę Łacińską i Afrykę, (2) analizę polskiego aspektu kolonializmu (głównie relacji ze wschodnimi sąsiadami) oraz (3) orientację literaturoznawczą. Tymi zagadnieniami zajmują się tacy naukowcy, jak Jan O. Kieniewicz, Jan Sowa, Ewa Majewska Thompson, Bolesław Bakuła oraz Marcin Moskalewicz.
} 
średniowieczu. Samowie utrzymywali stosunki handlowe z wikingami, dostarczając towarów, takich jak futra leśnych zwierząt, skóry i kości morskich ssaków, a także hodowanych przez siebie reniferów.

W okresie formowania się zrębów, a później już wytyczonych kształtów skandynawskich królestw coraz bardziej problematyczną kwestią stawała się zbiorowość Samów. Po pierwsze była ona nomadyczna, a więc nie zwracała uwagi na granice, jakie zostały wytyczone ponad głowami jej członków, po drugie znacząco różniła się od ówczesnego tzw. społeczeństwa głównego nurtu, praktykowała inne wierzenia, miała swoje "niezrozumiałe” dialekty, innymi słowy - posiadała zupełnie inną kulturę. W złożonym konglomeracie samskiej obyczajowości i wierzeń dostrzeżono ponadto elementy grzeszności i prymitywizmu. Tak postrzegali to pierwsi chrześcijańscy misjonarze, którzy przybyli w rejony dzisiejszej północnej Szwecji w XI wieku6. Podobnie działo się w Norwegii, gdzie w 1152 roku zaczęły tworzyć się zręby struktur kościoła rzymskokatolickiego ${ }^{7}$. Kilka wieków później, w okresie reformacji, na polu misyjnym pojawiły się wyraźne elementy polityczne, które nabrały szczególnego znaczenia w kontekście unii norwesko-duńskiej. Dania, jako silniejszy partner, dominowała nad Norwegią, narzucając jej schematy działań także w aspekcie chrystianizacji ziem. Norweskie rozporządzenia kościelne przetłumaczono na język duński i tym językiem rozbrzmiewał wśród Samów głos Kościołå ${ }^{8}$ Kluczowa dla działań protestanckich misjonarzy w Finnmark (prowincja na dalekiej północy Skandynawii) była polityczno-religijna instytucja Missions-Collegiet (później Missions-Collegium) ${ }^{9}$, utworzona w Kopenhadze w 1714 roku z rozkazu duńsko-norweskiego króla Fryderyka IV Oldenburga.

Sprawne działanie misji oraz jej wysoka skuteczność szybko wpłynęły na sposób postrzegania rzeczywistości przez Samów. Znaczące jest to, że przedchrześcijański okres nazywano wśród Samów Lule ${ }^{10}$ „czasem bębna”

${ }^{6}$ M. Pye, A.L. Svalastog, Colonial and Missionary Perceptions of Sami and Ainu in Sweden and Japan, „Bulletin” 2007, nr 36 (3), s. 72.

${ }^{7}$ A. Hoëm, Fra noaidiens verden til forskerens. Misjon, kunnskap og modernisering i sameland 1715-2007, Oslo 2007, s. 79.

8 Ibidem, s. 71.

${ }^{9}$ Więcej na jej temat: ibidem, s. 83.

${ }^{10}$ Określenie "Samowie Lule" związane jest z formowaniem na ziemiach Samów granic duńsko-norweskiej i szwedzkiej. Nazwę "Samowie Lule” stosowali misjonarze działający na końcu XVII wieku, co miało ułatwić identyfikowanie miejscowej, rdzennej 
(lule sam. goabdesájgge), natomiast czas pierwszych konfrontacji z misjonarzami powszechnie określano jako „czas, gdy trzeba było ukrywać bębny”"11. Było to bezpośrednie nawiązanie do praktykowanego przez Samów szamanizmu noaidevuohta ${ }^{12}$. Bęben (półn. sam. goavddis, lule sam. goabdes) jako istotny artefakt związany z performansem szamana (sam. noaide) stanowił dla misjonarzy jednoznaczny dowód „diabelskiej” działalności Samów.

Władze podjęły zatem kroki w celu zwalczenia starych wierzeń, interpretowanych przez przedstawicieli „właściwej wiary” jako zbyt grzeszne. Należało je wobec tego odpowiednio zmienić, a tym samym poddać protestanckiej modernizacji. Wszystko to $\mathrm{w}$ świetle prawa, zgodnie z kolejnymi aktami prawnymi. Charakterystyczne stało się to szczególnie dla przełomu XVII i XVIII wieku, gdy bębny używane przez noaidego, symbolizując rdzenną kulturę, były niszczone. Działo się tak, pomimo że Samowie od dekad uczestniczyli już w protestanckich obrzędach, umiejętnie łącząc stare wierzenia z nową wiarą. Głównym problemem misjonarzy nie były jednak sposób i jakość wykonywania chrześcijańskich rytuałów, ani nawet skuteczność w przekonywaniu rdzennej społeczności do dogmatów chrześcijaństwa, lecz opór do porzucania dawnych samskich wierzenn ${ }^{13}$. Samowie znajdujący się między odchodzącym w zapomnienie animistyczno-szamańskim światem przodków a żywotną kulturą przybyszów z Południa, reprezentowaną przez osadników, misjonarzy i urzędników, z trudem godzili się na funkcjonowanie według nowych reguł.

Istota znaczenia bębna tkwiła w szczególnej roli tego narzędzia w uwidacznianiu odrębności samskiej kultury. W wyrytych na jego membranie symbolach Samowie ulokowali wszystko to, co uważali za esencję swoich

ludności egzystującej przy granicy dzielącej Szwecję i Norwegię (obszar rozciągający się między współczesnymi Luleå a Bodø). Obecnie Samowie Lule chętnie wyrażają poczucie swej odrębności. Por. H. Rydving, The End of Drum-Time. Religious Change among the Lule Saami, 1670s-1740s, Uppsala 1993, s. 24.

${ }^{11}$ Idem, Tracing Sami Traditions. In Search of the Indigenous Religion among the Western Sami during the $17^{\text {th }}$ and $18^{\text {th }}$ Centuries, Oslo 2010, s. 39.

${ }^{12}$ Szamanizmowi noaidevuohta poświęciłam osobny tekst: M. Pawełko, Noaidevuohta. Performans w szamanizmie Samów, „Performer” 2017, nr 14 (Szamani, szeptuchy i psychodeliczne pająki), http://www.grotowski.net/performer/performer-14/noaidevuohta-performans-w-szamanizmie (dostęp 11 II 2018).

${ }^{13} \mathrm{Na}$ przełomie XVII i XVIII wieku bęben pełnił funkcję symbolu samskiego oporu przeciwko dominującej kulturze przybyszów. Por. H. Rydving, Tracing Sami Traditions..., op. cit., s. 40. 
wierzeń. Pogańska odmienność Samów, skoncentrowana w sercu kultury bębnie - została zinterpretowana przez Kościół jako dowód działalności Szatana.

Posądzenie o korzystanie ze wsparcia piekielnych mocy skutkowało procesami, które niekiedy kończyły się wyrokiem śmierci. Wśród oskarżonych znajdowali się przede wszystkim noaide - samscy szamani. Zimą 1671 roku w Kemi w fińsko-szwedzkiej części (szw. lappmark) Sápmi duchowni dostrzegli swoiste zagłębie "czarnoksięstwa” ${ }^{14}$, co rozpoczęło serię prześladowań.

Rdzenna społeczność jednak tylko częściowo podporządkowała się dominującej kulturze. Państwo zaostrzyło kary nie tylko za używanie, ale także za posiadanie i eksponowanie bębnów. W ósmej dekadzie XVII wieku nasility się opresje wobec Samów praktykujących szamanizm, zaś szamańskie artefakty intensywnie niszczono, zwłaszcza w szwedzko-fińskiej części Sápmi. Wymierzane kary miały odstraszać i być ostrzeżeniem dla innych ${ }^{15}$. Funkcjonariusze religijno-polityczni bazowali tu na powszechnie utrwalonym wśród osadników stereotypie „na wpół dzikich, lękliwych Lapończyków”, których do pewnych racji najłatwiej przekonać poprzez zastraszanie. Karanie często przybierało formę widowisk polegających na paleniu ułożonych na stosach samskich artefaktów należących do sfery sacrum, którymi w XVII wieku najczęściej były wspomniane bębny. Egzekucje samskich opozycjonistów stanowiły jednak znacznie bardziej wymowną i tym samym skuteczną formę zastraszenia.

Działalności misjonarzy sprzyjały polityczne uwarunkowania krajów dalekiej Północy. Szczególnie istotne jest to, że od czasów reformacji Kościół w unii duńsko-norweskiej stał się Kościołem narodowym, co w literaturze przedmiotu znajduje następujący opis:

Świecka część Kościoła była odtąd własnością króla, podczas gdy boska część służyła Bogu. [...] Nowością było to, że Kościół teraz stał się Kościołem narodowym zależnym od władcy, oraz to, że język ojczysty wiernych powinien stać się językiem Kościoła. To ukazywało siłę władcy, jednocześnie skutecznie wspierając jego władzę poprzez wzmocnienie poczucia narodowej jedności ${ }^{16}$.

\footnotetext{
${ }^{14}$ Ibidem.

${ }^{15}$ Ibidem, s. 40-41.

${ }^{16}$ A. Hoëm, Fra noaidiens..., op. cit., s. 71 . O ile nie zaznaczono inaczej, tłumaczenia na język polski pochodzą ode mnie - M.P.
} 
W przypadku siedemnastowiecznej Szwecji (powiązanej politycznie z Finlandią) sytuacja wyglądała podobnie. Celem, jaki przyświecał luterańskiemu Kościołowi narodowemu, także było zjednoczenie narodu poprzez wspólną wiarę. Można tu więc mówić nie tyle o duchownych, ile o funkcjonariuszach religijnych odgrywających rolę zarówno na płaszczyźnie religii, jak i w sferze polityki. Nic zatem dziwnego, że w 1686 roku w szwedzkim prawie kanonicznym zastrzeżono, że jedynie członkowie luterańskiego Kościoła narodowego mogą swobodnie przebywać w obrębie granic kraju, natomiast religijna jednolitość jest gwarantem trwałości systemu ${ }^{17}$.

Dla kwestii samskiej ma to znaczenie $z$ tego powodu, że kolonizacyjna działalność misjonarzy (będących reprezentantami władzy państwowej) wśród Samów bazowała na koncepcjach powiązanych z pietyzmem. Nacisk - dosłownie i w przenośni - położony został na indywidualną osobę, wobec czego duchowni wymagali, by każdy Sam i każda Samka umacniali się $w$ strukturze chrześcijańskiej, której fundament odnaleziono właśnie w pietyzmie ${ }^{18}$. Ta tendencja narastała od początku XVIII wieku, szczególnie w norweskiej części Sápmi ${ }^{19}$.

Przełom wieku XVII i XVIII zapisał się tragicznymi zgłoskami w historii kultury Samów - doprowadzono do całkowitej kolonizacji ludności autochtonicznej. Zmiany związane z tym okresem Håkan Rydving nazywa religijną enkulturacją i dekulturacją, która trwale zmieniła samską obyczajowość ${ }^{20}$. Charakteryzowało to szczególnie społeczność Samów Lule.

W piątej dekadzie XVIII wieku władze kościelne i polityczne nie dostrzegały wśród Samów Lule śladów starej religii i dawnych obyczajów, ponieważ Samowie sprawiali wrażenie „dobrych chrześcijan”, uczęszczając do kościoła i przystępując do sakramentów ${ }^{21}$. W tym czasie Samowie postrzegali swą kulturę jako gorszą, deprecjonującą ich egzystencję w świecie nowego porządku społecznego. W późniejszych dekadach skrywanie

${ }^{17}$ P. Markkola, The Lutheran Nordic Welfare States, [w:] Beyond Welfare State Models. Transnational Historical Perspectives on Social Policy, red. P. Kettunen, K. Petersen, Cheltenham - Northampton 2011, s. 105.

${ }^{18} \mathrm{H}$. Rydving, The End of..., op. cit., s. 162.

${ }^{19} \mathrm{~W}$ przypadku luteranizmu do XVII wieku szczególnym zainteresowaniem misjonarzy cieszyły się religijne praktyki parafian, natomiast w przypadku pietyzmu nacisk kładziono na rozwój chrześcijańskiej świadomości danej jednostki. Por. ibidem, s. 49.

${ }^{20}$ Ibidem, s. 161.

${ }^{21}$ Ibidem, s. 167. 
materialnych dowodów przynależności do rdzennej kultury praktykowane było (przez część Samów) bez odgórnego nakazu. Prowadziło to nie tyle do utrwalania podziału na "światłych" reprezentantów nordyckiego porządku, co do umacniania wzajemnej nieufności wśród autochtonów. Wszak część stała się pokoleniem konwertytów, podczas gdy nieliczni potajemnie czcili to, co dawno powinno zniknąć, gdyż należało do przodków. Jak zaznacza Håkan Rydving, nastał "czas, gdy bębny należało skrywać"22.

Nie bez znaczenia jest fakt, iż w owym okresie przedstawiciele dominujących kultur dostrzegli w rejonie Sápmi obszary atrakcyjne pod względem eksploatacyjnym, przemysłowym. Umacnianie podziałów wzdłuż granicy duńsko-norweskiej oraz szwedzko-fińskiej na terenach Sápmi nie miało zatem przyczyn jedynie związanych z krzewieniem chrześcijaństwa.

Lata 20. i 30. XX wieku to szczególnie ponury czas w historii Samów. Rozwijała się wtedy socjaldemokratyczna idea folkhemmet, czyli domu ludu, bazująca na inicjatywie eugenicznejej. W tym okresie pojawiła się koncepcja „Lapończyka, który musi zostać Lapończykiem”24, skorelowana z działaniami badaczy zajmujących się antropologią fizyczną i biologią rasową. Władze szwedzkie i norweskie uznały Samów za predestynowanych do hodowli reniferów, więc autochtoni zajmujący się w większości innymi pracami, na przykład myślistwem i rybołówstwem, przestali być już uznawani za Samów. Naukowy pierwiastek okazał się w tym przypadku przydatny, ponieważ dzięki biologii rasowej analiza fizjonomii Samów także "wykazała”, iż należy „usankcjonować” pośledniość „lapońskiej rasy”. Samowie $w$ to uwierzyli.

22 Ibidem.

${ }^{23}$ Ze względu na brak miejsca na wyjaśnienia odsyłam do mojego artykułu na ten temat: M. Pawełko, Dom ludu i higiena rasy. Inicjatywa eugeniczna w szwedzkim stylu, „Maska. Magazyn antropologiczno-społeczno-kulturowy” 2017, nr 35 (Apokalipsa - Zagłada), s. 255-268.

${ }^{24}$ N.D. Broadbent, Lapps and Labyrinths: Saami Prehistory, Colonization and Cultural Resilience, Washington, DC 2010, s. 8. 


\section{JEDNI Z OSTATNICH WOLNYCH LUDZI - SAMOWIE KOLSCY 25}

Nieco już archaiczny, pochodzący z etnologii nordyckiej, podział na Samów leśnych, górskich i morskich ${ }^{26}$ uwidacznia mimo wszystko pewną charakterystyczną cechę samskiej kultury: jest ona niezwykle heterogeniczna. Ukształtowanie terenu, na który składała się tundra, góry, fiordy, a przede wszystkim wewnętrzne zróżnicowanie samskiej kultury i na wpół nomadyczny styl życia również nie sprzyjały kulturowej homogenizacji.

Jeszcze większa odmienność cechuje Samów spoza nordyckiego kręgu kulturowego. Chodzi o Samów z zachodnio-północnego obszaru współczesnej Rosji, mieszkających od prawieków w regionie dziś nazywanym Półwyspem Kolskim. Współegzystowali tam ze społecznościami Komiaków i Karelów. Przy czym relacje Samów z Komiakami w przeszłości charakteryzowały się wyraźną wrogością i antagonizmem ${ }^{27}$. Stan ten widoczny był zwłaszcza przed wybuchem pierwszej wojny światowej, gdy dla niektórych rosyjskich badaczy Samowie, w przeciwieństwie do Komiaków, „nie byli pasterzami reniferów w prawdziwym tego słowa znaczeniu", byli zatem gorsi ${ }^{28}$.

Podobnie jak przy Samach nordyckich (norweskich i szwedzkich), w przypadku Samów kolskich należy zacząć rozważania od kwestii związanych z religią.

Jedna ze wzmianek dotyczących tworzenia się nowych struktur organizacyjnych na terenie rdzennie samskim podaje rok 1556. Wtedy to

\footnotetext{
${ }^{25}$ Aby ułatwić badania kultury Samów z półwyspu, współcześnie część naukowców wyróżnia elementy odróżniające przedstawicieli rdzennej społeczności wynikające z lingwistycznej odmienności tej grupy narodowej. Przekłada się to na istnienie (coraz bardziej zagrożonych zanikiem) dialektów ter, skolt, kildin oraz akkala. Por. F. Siegl, M. Riessler, Uneven Steps to Literacy. The History of the Dolgan, Forest Enets and Kola Sámi Literacy Languages, [w:] Cultural and Linguistic Minorities in the Russian Federation and the European Union. Comparative Studies on Equality and Diversity, red. H.F. Marten, M. Riessler, J. Saarikivi, R. Toivanen, Cham - Heidelberg - New York - Dordrecht - London 2015, s. 191.

${ }^{26}$ Więcej na ten temat w: E. Manker, $\varnothing$. Vorren, Lapończycy. Zarys historii kultury, przeł. T.A. Malanowski, Warszawa 1980.

${ }^{27}$ Antagonizm między Samami a Komiakami wynikał z odmienności stylu życia obu grup społecznych. Była to konfrontacja między Samami - ówcześnie głównie myśliwymi oraz łowcami - a Komiakami będącymi społecznością zajmującą się hodowlą reniferów. Por. A. Bruno, The Nature of Soviet Power. An Arctic Environmental History, New York St. Ives 2016, s. 129-130.

${ }^{28}$ Ibidem, s. 130.
} 
prawosławny Święty Trifan otrzymał zgodę Iwana Groźnego, aby stworzyć na ziemiach Samów strefę wpływów monasteru29. Wkrótce „,[..] nadano mu wielki obszar na Półwyspie Kola i nad rzeką Tuloma. [...] stał się ośrodkiem ich [Samów] życia duchowego [...] miał też decydujący wpływ na życie świeckie. Zewsząd ściągali do niego pielgrzymi, wzmacniając i rozbudowując łączność z państwem i życiem narodu rosyjskiego"30.

Jednak początek rosyjskiej kolonizacji terenów należących do Samów datuje się na 1721 rok, gdy Półwysep Kolski zaczęto oficjalnie włączać w obręb terenów rosyjskiej władzy ${ }^{31}$. Proces kolonizacyjny przybrał na sile od 1868 roku $^{32}$.

W przeciwieństwie do Samów z nordyckiego kręgu kulturowego autochtoni z obszaru Półwyspu Kolskiego najdobitniej przekonali się o potędze władzy na skutek działań nie funkcjonariuszy religijnych, lecz politycznych propagatorów władzy. Wiązało się to głównie z faktem, iż promowany przez ZSRR ateizm nie współgrał $z$ animizmem i szamanizmem Samów ${ }^{33}$.

Na początku XX wieku, gdy bolszewicy umocnili swoją pozycję, pojawił się koncept eksperymentu polegającego na podniesieniu rangi rdzennych społeczności poprzez uznanie ich jako części składowej Związku Radzieckiego ${ }^{34}$. Rdzenna społeczność mogła się przydać. W samskim sposobie hodowania reniferów dostrzeżono ekonomicznie pożyteczne dla regionu rozwiązania ${ }^{35}$. Te działania zostały jednak przerwane przez wybuch pierwszej wojny światowej. W jej wyniku Samowie stracili ponad $70 \%$ stad reniferów ${ }^{36}$.

W drugiej dekadzie XX wieku radzieckie wpływy ostatecznie rozciągnęły się na Półwysep Kolski, a tym samym zainicjowano epokę kolektywizacji dobytku miejscowej społeczności samskiej, natomiast sporadyczne

${ }^{29}$ E. Manker, $\varnothing$. Vorren, Lapończycy..., op. cit., s. 89.

${ }^{30}$ Ibidem.

${ }^{31}$ J. Minahan, Encyclopedia of the Stateless Nations: S-Z, Westport - London 2002, s. 1638.

${ }^{32}$ Ibidem, s. 1639.

${ }^{33}$ T. Kvitberg, "Suffering in Body and Soul". Lived Life and Experiences of Local Food Change in the Russian Arctic, [w:] Idioms of Sámi Health and Healing, red. B.H. Miller, E. Waugh, Edmonton 2015, s. 107.

${ }^{34}$ A. Bruno, The Nature..., op. cit., s. 134.

35 Ibidem.

${ }^{36}$ Ibidem. 
akty nieposłuszeństwa karano wysiedleniami i egzekucjami ${ }^{37}$. Tego rodzaju rosyjskie „bodźce” nieodwracalnie wpłynęły na zmianę sposobu postrzegania przez Samów ich miejsca na świecie. Groźba śmierci lub deportacji była w tym przypadku niedookreślona, wszak nie związano jej z konkretnym, oficjalnym rozporządzeniem ani z ustanowieniem instytucji, jak w przypadku nordyckim. Nastroje społeczne na Półwyspie Kolskim w tym okresie zostały więc uwarunkowane nieoczekiwanymi dla rdzennej społeczności, nieusankcjonowanymi prawnie działaniami funkcjonariuszy politycznych. Trudno tu zatem mówić o skwapliwym roztrząsaniu stricte sprawy samskiej na arenie politycznych rozgrywek ZSRR w latach 20. XX wieku. Samowie kolscy zostali bowiem wchłonięci przez to, co zgotowano wszystkim „małym ludom" z terenów sukcesywnie włączanych, by nie powiedzieć „oswajanych", przez radzieckie uniwersum.

Władze radzieckie uplasowały Samów, tak samo jak Nieńców i dwadzieścia cztery pozostałe grupy etniczne, w kategorii „niewielkich społeczności z północy". Takie określenie oznaczało, że przyporządkowano im najniższą pozycję w wyobrażonej, ewolucyjnej skali mniejszości narodowych ${ }^{38}$.

Charakterystyczne dla tego okresu nakazy porzucenia dotychczasowego stylu życia (łowcy, myśliwego oraz hodowcy reniferów) i opuszczenia zajmowanej ziemi celem wzięcia udziału w państwowych brygadach produkcyjnych ${ }^{39}$ wpisują się w ogólny schemat ówczesnych rosyjskich praktyk w stosunku do mniejszości etnicznych ${ }^{40}$.

W czasie drugiej fali kolektywizacji działania władz na terenach samskich stały się bardziej ofensywne. Między 1933 a 1941 rokiem otwarcie zawłaszczano obszary Sápmi i pozbawiano Samów praw do ziem użytkowanych od wieków ${ }^{41}$. Rosyjską część Sápmi uznano oficjalnie za własność ZSRR, a osoby usiłujące wyrażać niezadowolenie czy krytycyzm poddawano stalinowskim czystkom ${ }^{42}$.

${ }^{37}$ K.-A.S. Kassam, M.P. Robinson, Sami Potatoes: Living with Reindeer and Perestroika, Calgary 1998, s. 13.

${ }^{38}$ A. Bruno, The Nature..., op. cit., s. 138.

39 J.B. Henriksen, Saami Parliamentary Co-Operation: An Analysis, Copenhagen Guovdageaidnu 1999, s. 77.

${ }^{40}$ F. Siegl, M. Riessler, Uneven Steps..., op. cit., s. 190.

${ }^{41}$ K.-A.S. Kassam, M.P. Robinson, Sami Potatoes..., op. cit., s. 13.

${ }^{42}$ Ibidem. 
Ingerencja w samskie umowne granice na początku XX wieku zyskała realną postać $w$ wypowiedziach rosyjskich geologów współpracujących z systemem komunistycznym. Znajdował się wśród nich badacz Aleksandr Fersman ${ }^{43}$, który opisywał obszar kolski w następujących słowach:

Nie sposób zapomnieć wrażenia [...] jakie wywarła na nas obszerna panorama aż do horyzontu. Wszystko tam było nowe i nieoczekiwane: przed nami ciągnęły się pasma gór bez liku, potężnymi grzbietami uchodzące na wschód, co nijak nie przystawało do dotychczasowych wyobrażeń. Skąd się wzięły owe górskie łańcuchy tam, gdzie na mapach widniały niziny? To był zupełnie nowy, nikomu wcześniej nieznany górski świat. No i te niezwykłe kamienie! W niektórych wypadkach nie umiałem nazwać ani jednego z minerałów [...]. Od razu postanowiłem zbadać ten region za wszelką cenę ${ }^{44}$.

Widoczne ekspansjonistyczne skłonności radzieckich badaczy były wspierane przez władzę, której zależało na zasobach surowcowych, w tym minerałach ${ }^{45}$. Wspomniany Fersman zorganizował grupę badaczy, którzy by zacytować Wilka -

[...] dosłownie przekopali Chibińskie i Łowozierskie Tundry (tylko w latach 1920-1922 przeszli około tysiąca pięciuset kilometrów i odkryli ponad sto złóż mineralnych). Powstawały wielkie kombinaty wydobywczo-przemysłowe, rosły miasta (Moczegork, Chibiny, Kirowsk), zjeżdżali się ludzie w pogoni za „długim rublem"46.

Z kolei sam Fersman pisał o rosyjskich poczynaniach w ten oto sposób:

To nie żadna fantazja, nie bajka, lecz rezultat działalności bolszewickiej. Zwycięstwo w walce z przyrodą! Pokonaliśmy kraj niestrachliwych ptaków, tundrę bezmowną, w zimie białą od śniegu, w lecie od chrobotka reniferowego ${ }^{47}$.

${ }^{43}$ Aleksandr Fersman (1883-1945) był geologiem i geochemikiem szczególnie zasłużonym dla ZSRR. Swoją działalnością naukową pragnął udowodnić potęgę socjalizmu. Celem jego wyprawy w rejony masywu górskiego Chibiny, oprócz odkrycia złóż fosforanu, było wyeksponowanie wszechpotęgi Rosji. Por. A. Bruno, The Nature..., op. cit., s. 73.

${ }^{44}$ M. Wilk, Tropami rena, Warszawa 2007, s. 102.

${ }^{45}$ Ibidem.

46 Ibidem.

${ }^{47}$ Ibidem. 
Dzięki mobilizacji środków finansowych oraz siły roboczej Związek Radziecki zdołał z powodzeniem wprowadzić stalinowską ideę „socjalizmu w jednym kraju" także na arktyczne obrzeża Półwyspu Kolskiego ${ }^{48}$.

Pod koniec lat 20. XX wieku sowieckie władze zdecydowały radykalnie przyśpieszyć rozwój przemysłowy w całym kraju. Pragnienia, by dogonić, pod względem ekonomicznym, kapitalistyczny Zachód, by wesprzeć bezpieczeństwo narodowe [...], oraz aby ożywić bolszewickie, rewolucyjne obietnice w stalinowskim przebraniu, pomogły w rozwoju tej powszechnej kampanii ${ }^{49}$.

W 1927 roku, z inicjatywy Rosyjskiego Towarzystwa Geograficznego, wyruszyła „lapońska ekspedycja”, której celem stały się badania z zakresu antropologii fizycznejej. Na ziemi bezcennej, bo ojczyźnianej dla Samów, poszukiwano także złóż niklu, apatytów, eudialitów, a szczególne pożądanie wzbudzał łoparit ${ }^{51}$. Przełożyło się to na zwiększenie zaludnienia w miejscach kolejnych odkryć minerałów. W latach 30. XX wieku Półwysep Kolski stopniowo stawał się jednym z najbardziej zasiedlonych terenów Arktyki, do czego przyczynił się masowy napływ robotników z głębi Rosji ${ }^{52}$. Wkrótce dewastacji uległ samski krajobraz. Zimą 1945 roku na Karnasurcie - świętej górze Samów - odkryto wyjątkowo bogate i łatwe do wydobycia złoża łoparitu ${ }^{53}$.

Przełom lat 50. i 60. to apogeum kryzysu kulturowego, który cechował się przemocą fizyczną, całkowitym niszczeniem samskiego dobytku, w tym całych osad i wiosek, przez funkcjonariuszy reżimu ZSRR ${ }^{54}$. W kolejnej dekadzie powiązania przemysłu i nauki okazały się ciosem dla społeczności kolskich Samów. Obszar oficjalnie nieuznawany już za samski stał się bowiem terenem agresywnej ingerencji oraz naukowych eksperymentów. Środowisko naturalne, ziemia naznaczona świętymi górami - wszystko to uległo degradacji. Przyczyniły się do tego „pokojowe” detonacje bomb jądrowych, budowa elektrowni jądrowej z czterema reaktorami oraz magazynowanie odpadów radioaktywnych w dawniej żywym kulturowo mateczniku Samów kolskich ${ }^{55}$.

\footnotetext{
${ }^{48}$ A. Bruno, The Nature..., op. cit., s. 73.

${ }^{49}$ Ibidem, s. 73-74.

50 Ibidem, s. 139.

${ }^{51}$ M. Wilk, Tropami rena, op. cit., s. 102-103.

${ }^{52}$ A. Bruno, The Nature..., op. cit., s. 74.

${ }^{53}$ M. Wilk, Tropami rena, op. cit., s. 103-104.

${ }^{54}$ T. Kvitberg, "Suffering in Body and Soul"..., op. cit., s. 107.

${ }^{55}$ K.-A.S. Kassam, M.P. Robinson, Sami Potatoes..., op. cit., s. 14.
} 
Radziecka „modernizacja” sposobu życia „małego narodu Północy” trwale zmieniła oblicze samskiego etosu. Jednych z ostatnich wolnych ludzi Europy zmuszono do gromadzenia się w przeludnionych rosyjskich miastach półwyspu, których mieszkańców trawił nałóg alkoholizmu ${ }^{56}$. Samowie zostali postawieni przed wyborem między szukaniem pracy $\mathrm{w}$ takim a nie innym miejscu a egzystowaniem z dala od radzieckiej „cywilizacji”, wśród samskiej tundry, postrzeganej pod koniec ZSRR jako synonim braku perspektyw ${ }^{57}$.

\section{PERSPEKTYWY (MIMO WSZYSTKO)}

Z powyższego obrazu wyłania się panorama głęboko zranionej społeczności, wtłaczanej w poczucie wstydu, pozbawianej poczucia przynależności, a przez to skazywanej na egzystencję w nieustannej niepewności i rozdarciu między dwiema kulturami: przodków i przybyszów. Przywołane ważniejsze wydarzenia związane z kolonizacją ludności samskiej, a także z formowaniem granic na jej terenach zmuszają do zadania pytania, kim są i dokąd zmierzają współcześni Samowie.

Odpowiedzią niech będzie samski aktywizm. Dzięki podejmowanym dotychczas działaniom, mającym na celu transgraniczną współpracę autochtonów Północy, stworzono struktury (w tym parlamenty) i akty prawne wzmacniające obecną pozycję Samów, także na arenie międzynarodowej ${ }^{58}$. To wszystko jest jednak świadectwem czegoś znacznie istotniejszego, pulsującego we współczesnej kulturze Samów. Obecnie można już mianowicie otwarcie mówić o samskim odrodzeniu, dostrzegalnym zwłaszcza w artystycznych działaniach pokolenia urodzonego pod koniec XX wieku. Stopniowe przepracowanie traum z przeszłości prowadzi Samów do jednomyślnego stwierdzenia, artykułowanego na kolejnych polityczno-kulturalnych zjazdach, iż są oni jednym narodem, podzielonym czterema granicami, a mimo wszystko jednoczącym się na polu kultury i historiii ${ }^{59}$.

${ }^{56}$ T. Kvitberg, „Suffering in Body and Soul”..., op. cit., s. 107.

57 Ibidem.

${ }^{58}$ Szczegółowiej wyjaśniono to w: J.B. Henriksen, Saami Parliamentary..., op. cit.

${ }^{59}$ Więcej na ten temat w: The Proposed Nordic Saami Convention: National and International Dimensions of Indigenous Property Rights, red. N. Bankes, T. Koivurova, Oxford - Portland 2013. 


\section{BIBLIOGRAFIA}

Aakala T., Kuuluvainen T., Natural Forest Dynamics in Boreal Fennoscandia: A Review and Classification, „Silva Fennica” 2011, nr 45 (5), s. 823-841, https://doi.org/10.14214/sf.73.

Banaś M., Pogranicza kulturowe. Kultura Samów wobec szans i zagrożeń współczesności, [w:] Granice w kulturze, red. R. Bomba, A. Radomski, Lublin 2010, s. 35-44.

Broadbent N.D., Lapps and Labyrinths: Saami Prehistory, Colonization and Cultural Resilience, Washington, DC 2010.

Bruno A., The Nature of Soviet Power. An Arctic Environmental History, New York - St. Ives 2016.

Donner J., The Fennoscandian Shield Within Fennoscandia, „Bulletin of the Geological Society of Finland" 1996, nr 68 (1), s. 99-103.

Henriksen J., Saami Parliamentary Co-Operation: An Analysis, Copenhagen - Guovdageaidnu 1999.

Hoëm A., Fra noaidiens verden til forskerens. Misjon, kunnskap og modernisering $i$ sameland 1715-2007, Oslo 2007.

Kassam K.-A.S., Robinson M., Sami Potatoes: Living with Reindeer and Perestroika, Calgary 1998.

Kvitberg T., "Suffering in Body and Soul". Lived Life and Experiences of Local Food Change in the Russian Arctic, [w:] Idioms of Sámi Health and Healing, red. B.H. Miller, E. Waugh, Edmonton 2015, s. 103-130.

Manker E., Vorren $\varnothing .$, Lapończycy. Zarys historii kultury, przeł. T.A. Malanowski, Warszawa 1980.

Markkola P., The Lutheran Nordic Welfare States, [w:] Beyond Welfare State Models. Transnational Historical Perspectives on Social Policy, red. P. Kettunen, K. Petersen, Cheltenham Northampton 2011, s. 102-118.

Minahan J., Encyclopedia of the Stateless Nations: S-Z, Westport - London 2002.

Pawełko M., Dom ludu i higiena rasy. Inicjatywa eugeniczna w szwedzkim stylu, „Maska. Magazyn antropologiczno-społeczno-kulturowy" 2017, nr 35 (Apokalipsa - Zagłada), s. 255-268.

Pawełko M., Noaidevuohta. Performans w szamanizmie Samów, „Performer” 2017, nr 14 (Szamani, szeptuchy i psychodeliczne pająki), http://www.grotowski.net/performer/performer-14/noaidevuohta-performans-w-szamanizmie (dostęp 1 II 2018).

Pye M., Svalastog A.L., Colonial and Missionary Perceptions of Sami and Ainu in Sweden and Japan, „Bulletin” 2007, nr 36 (3), s. 70-75.

Rydving H., The End of Drum-Time. Religious Change among the Lule Saami, 1670s-1740s, Uppsala 1993.

Rydving H., Tracing Sami Traditions. In Search of the Indigenous Religion among the Western Sami during the $17^{\text {th }}$ and $18^{\text {th }}$ Centuries, Oslo 2010.

Rydving H., Words and Varieties. Lexical Variation in Saami, Helsinki 2013.

Saami Linguistics, red. D.C. Nelson, I. Toivonen, Amsterdam - Philadelphia 2007.

Sammallahti P., Saamic, [w:] The Uralic Languages, red. D. Abondolo, London - New York 1998, s. 43-95.

Siegl F., Riessler M., Uneven Steps to Literacy. The History of the Dolgan, Forest Enets and Kola Sámi Literacy Languages, [w:] Cultural and Linguistic Minorities in the Russian Federation and the European Union. Comparative Studies on Equality and Diversity, red. H.F. Marten, M. Riessler, J. Saarikivi, R. Toivanen, Cham - Heidelberg - New York - Dordrecht - London 2015, s. 189-230. 
The Proposed Nordic Saami Convention: National and International Dimensions of Indigenous Property Rights, red. N. Bankes, T. Koivurova, Oxford - Portland 2013.

Wilk M., Tropami rena, Warszawa 2007.

\title{
SÁPMI. THE SAMI LAND AND BOUNDARIES FORMATION OF NORTHERN EUROPE
}

\begin{abstract}
Sápmi is an area strongly connected with culture of the Sami people, the indigenous inhabitants of Northern Europe. Gradual formation of nation states - Russia and Scandinavian kingdoms - had negative impact on lifestyle of the Sami people. This impact had a significant influence on their mentality and modification of the genuine culture. The paper aims to study the main effects of boundaries formation of nation states for culture of the autochthons of Northern Europe.
\end{abstract}

Key words: the Sami people, Sweden, Norway, Finland, Kola Peninsula 